\title{
The Relation of Uric Acid And MPV Levels And Cognitive Functions In Fibromyalgia
}

\section{Fibromiyalji Sendromunda Serum Ürik Asit ve Ortalama Trombosit Hacmi Düzeylerinin Bilişsel Fonksiyonla İlişkisi}

\author{
Meltem Vural $^{1 \oplus}$, Filiz Yıldız Aydın ${ }^{1} \oplus$, Bahar Cakmak ${ }^{1 \oplus}$, Isil Ustun ${ }^{1}$, Ali Bayram Kasım ${ }^{2} \oplus$ \\ Asuman Gedikbasi ${ }^{3,4} \oplus$, Cemal Bes $^{5} \oplus$
}

${ }^{1}$ Health Sciences University Bakirkoy Dr Sadi Konuk Training and Research Hospital Physical Medicine and Rehabilitation Clinic, Istanbul, Turkey ${ }^{2}$ Health Sciences University, Bakirkoy Dr Sadi Konuk Training and Research Hospital Family Medicine Clinic, Istanbul, Turkey ${ }^{3}$ Istanbul University, Institute of Child Health, Department of Pediatric Basic Science, Medical Genetics, Istanbul, Turkey ${ }^{4}$ Health Sciences University, Bakirkoy Dr Sadi Konuk Training and Research Hospital Biochemistry Clinic, Istanbul, Turkey ${ }^{5}$ Health Sciences University, Bakirkoy Dr Sadi Konuk Training and Research Hospital Rheumatology Clinic, Istanbul, Turkey

Received: 20.05.2020 / Accepted: 03.11.2020 / Published Online: 29.12.2020

Cite as: Vural M, Yildiz Aydin F, Cakmak B, Ustun I, Kasım AB, Gedikbasi A, Bes C. The relation of uric acid and MPV levels and cognitive functions in fibromyalgia. Med J Bakirkoy 2020;16(4):317-23.

ABSTRACT

Objective: Patients with fibromyalgia syndrome (FMS) have mild cognitive dysfunction. Higher serum uric acid (UA) levels in some diseases are reported to be associated with cognitive impairment. Mean platelet volume (MPV) is an indicator of platelet activation. Activated platelets may play a role in neuroinflammation and cognitive dysfunction. The purpose of this study was to compare cognitive functions of FMS patients and controls and investigate the relation of serum UA and MPV levels with cognitive functions.

Method: Fifty-four patients with FMS and 33 healthy controls were enrolled, retrospectively. Evaluations were performed with Visual Analog Scale (VAS), Fibromyalgia Impact Questionnaire (FIQ), Beck Depression Inventory(BDI) and to asses phychological status and cognitive impairment Mini Mental State Examination(MMSE) was used in both groups.

Results: Mean VAS and sleep quality of FMS group were significantly higher than the control group (p<0.05). Mean MMSE score was statistically significantly lower in the FMS group $(p=0.0001)$. There was not statistically significant correlation between serum UA levels and VAS pain/sleep quality, FIQ, BDI and MMSE scores ( $p>0.05)$. No significant correlation was found between serum MPV levels and VAS pain/ sleep quality, FIQ, BDI and MMSE scores ( $p>0.05$ ) but declined cognitive functions were determined in the FMS group when compared with the control group.

Conclusion: Declined cognitive functions were determined in the FMS the FMS group when compared with the control group. Although we did not determine an association of serum uric acid and MPV levels with cognitive functions, larger prospective studies with longer follow up periods are warranted to elucidate the role of these biomarkers in FMS and to determine the factors affecting cognitive functions.

Keywords: Fibromyalgia syndrome, cognitive function, uric acid, mean platelet volume

öz

Amaç: Çalışmalar Fibromiyalji sendromlu (FMS) hastalarda orta derecede kognitif bozukluk olduğunu göstermiştir. Serum ürik asit (ÜA) düzeyleri ile bazı hastalıklarda bilişsel bozukluklar arasındaki ilişki rapor edilmiştir. Ortalama trombosit hacmi (OTH) trombosit aktivasyonunun bir göstergesidir. Aktive trombositler nöroinflamasyon ve bilişsel işlev bozukluğunda rol oynayabilir. Amaç, FMS hastalarında serum ÜA ve OTH düzeylerinin yanı sıra FMS hastaları ve kontrolleri arasındaki bilişsel işlevleri karşılaştırmak ve FMS hastalarında ÜA, OTH ve bilişsel bozukluk arasındaki ilişkiyi araştırmaktı.

Yöntem: 54 FMS hastası ve 33 sağlıklı kontrol retrospektif olarak değerlendirildi. Ağrıyı değerlendirmek için Visuel Analog Skala (VAS), fonksiyonel durumu değerlendirmek için Fibromiyalji Etki Anketi (FEA), Mini Mental Test (MMT) ile psikolojik durumu ve bilişsel bozukluğu değerlendirmek için Beck Depresyon Envanteri (BDE) kullanıldı

Bulgular: FMS grubunun ortalama VAS ve uyku kalitesi kontrol grubuna göre anlamlı olarak yüksek bulundu ( $p<0.05)$. Ortalama MMT skoru $F M S$ 'de kontrollere göre istatistiksel olarak anlamlı derecede düşüktü $(p=0.0001)$. Serum ÜA düzeyleri ile VAS ağrı / uyku kalitesi, FEA, BDE ve MMT skorları arasında istatistiksel olarak anlamlı bir ilişki saptanmadı ( $p>0.05$ ). Serum MPV düzeyleri ile VAS ağrı / uyku kalitesi, FEA, BDE ve MMT skorları arasında anlamlı bir ilişki bulunmadı ( $p>0.05)$, ancak bilişsel işlevler kontrol olgularına göre azaldı.

Sonuç: FMS'de kontrol olgularından daha düşük bilişsel işlevler saptandı. Serum ürik asit ve MPV düzeyleri ile bilişsel işlevler arasında bir ilişki belirlememiş olsak da, bu biyobelirteçlerin FMS'deki rolünü aydınlatmak ve bilişsel işlevleri etkileyen faktörleri belirlemek için daha uzun takip süreleri olan daha geniş prospektif çalışmalar yapılması gerekmektedir.

Anahtar kelimeler: Fibromiyalji sendromu, bilişsel fonksiyon, ürik asit, ortalama trombosit hacmi

Corresponding Author:

isil_altan@yahoo.com.tr
M.Vural 0000-0003-4360-8318

F. Yildız Aydın 0000-0003-4763-7538

B. Çakmak 0000-0003-0938-8059
I. Ustun 0000-0001-7305-6839

A.B. Kasım 0000-0003-4376-3684

A. Gedikbasi 0000-0001-7121-6077

(c) Telif hakkı Sağlık Bilimleri Üniversitesi Bakırköy Dr. Sadi Konuk Eğitim ve Araştırma Hastanesi'ne aittir. Logos Tıp Yayıncılık tarafindan yayınlanmaktadır. Bu dergide yayınlanan bütün makaleler Creative Commons Atff-GayriTicari 4.0 Uluslararası Lisansı ile lisanslanmıştr.

(c) Copyright Health Sciences University Bakırköy Sadi Konuk Training and Research Hospital. This journal published by Logos Medical Publishing.

Licenced by Creative Commons Attribution-NonCommercial 4.0 International (CC BY) 


\section{INTRODUCTION}

Fibromyalgia syndrome (FMS) is a chronic pain syndrome, effecting about 3-6\% of population and mainly women ${ }^{(1)}$. It is mostly characterized by diffuse and generalized musculoskeletal pain; sleep disturbance, fatigue and morning stiffness ${ }^{(2)}$. Accompanying these symptoms, patients with FMS commonly complain from physical and cognitive impairments ${ }^{(3)}$. Moreover, recently, significant deficiencies in the daily living functions have been reported in patients with FMS (4). However, it should also be kept in mind that, FMS patients are generally treated with centrally acting drugs which can also cause cognitive impairments ${ }^{(5)}$.

The role of oxidative stress in cognitive impairment has been shown exactly ${ }^{(6)}$. Uric acid is a member of antioxidant system with its some properties such as scavenging hydroxyl radicals, and peroxynitrite and stabilizing other antioxidant systems including superoxide dismutase and ascorbic acid ${ }^{(7)}$. Reduced uric acid levels, as marker of augmented oxidative stress, have been associated with cognitive impairment in some diseases before ${ }^{(8,9)}$. However, recently, elevated levels of uric acid levels, with its vascular effects, were also associated with decline in cognitive functions ${ }^{(10)}$. To the best of our knowledge the role of uric acid levels in cognitive functions of patients with FMS has not been investigated before.

Other than oxidative stress, inflammation is also a factor accused in the development of cognitive impairment ${ }^{(11)}$. Mean platelet volume (MPV) is a marker of activated platelets and has been associated with many inflammatory conditions ${ }^{(12-14)}$. On the other hand, elevated MPV levels were also reported in patients with Alzheimer disease having cognitive impairments ${ }^{(15)}$.

Factors affecting the cognitive functions of patients with FMS are critically important since this condition may alter the life quality of patients. To the best of our knowledge, data about the cognitive impairments in FMS patients is limited. In this study we aimed to compare the cognitive functions of FMS patients with control cases and to determine the effects of uric acid, as a marker of antioxidant status, and of MPV as a marker of inflammation, on cognitive functions in FMS.

\section{MATERIAL and METHODS}

This study was carried out in Bakırkoy Training Hospital Physical Medicine and Rehabilitation Department, between December 2014 and February 2015. Totally 54 premenopausal female patients with FMS diagnosed according to 1990, 2010 and 2013 ACR Physical Medicine and Rehabilitation, retrospectively and 33 volunteer healthy age-matched premenopausal women were enrolled. Exclusion criteria were menopausal status, presence of a systemic disorder including hypertension, diabetes mellitus, hematologic disease, autoimmune diseases, renal failure, liver diseases, steroid and anticoagulant use, infectious, inflammatory and cardiovascular diseases, serious psychiatric disorders involving psychotic symptoms, recent risk of suicide or substance abuse and/or neurological disease, pregnancy and abnormal results of routine examinations. The present study has been approved by Local Ethics Committee.

\section{Demographic and Clinical Information}

Patient characteristics, mean disease duration, symptoms accompanying FMS and number of tender points were determined. Age (year), height $(\mathrm{cm})$, weight $(\mathrm{kg})$, body mass index (BMI; calculated as weight in kilograms divided by height in meters squared $: \mathrm{kg} / \mathrm{m}^{2}$ ) presence of fatigue, morning stiffness, sleep disturbance, morning fatigue, paresthesia, headache, Raynaud's phenomena, irritable bowel syndrome, sicca symptoms, female urethral syndrome, sensation of tissue swelling and dysmenorrhea were all recorded.

\section{Laboratory Findings}

Venous blood samples were obtained from the antecubital vein, followed by 12 hours fasting. The tubes were centrifuged at $2000 \mathrm{~g}$ for $10 \mathrm{~min}$ and then the serum portions of the blood samples were discarded The samples were analyzed within an hour. In all cases, MPV and platelet counts were calculated as part of each complete blood count. Complete blood count was measured using Coulter LH 750 auto-analyser (Beckman Coulter, CA, USA). From the blood tests, parathormon (PTH), thyroid stimulating hormone (TSH) and other biochemical parameters were recorded to rule out other diseases mimicking FMS. These parameters were determined by Beckman Coulter's AU5800 Clinical Chemistry, DXI 800 immunoassay auto-analyser and using commercial kits (Beckman Coulter, CA, USA). 
Serum C-reactive protein (CRP) was measured with Siemens BNII nephelometric system (Siemens Healthcare Diagnostics, USA) using reagents and protocols provided by the manufacturer.

Visual Analog Scale (VAS) was used to evaluate pain and sleep quality, and Fibromyalgia Impact Questionnaire (FIQ) wasused to assess functional status of patients. Beck Depression Inventory (BDI) was used to evaluate depressive symptoms and the frequency of cognitive impairment was evaluated with Mini Mental State Examination (MMSE) ${ }^{(16) .}$

VAS is a measurement instrument used to assess pain and sleep quality. It is a 10-cm scale with "no pain" at the beginning and "the worst possible pain" at the other end. Scores are recorded by the patient with a mark on the line according to pain intensity. Sleep quality was also evaluated by a similar scale $10 \mathrm{~cm}$ in length, "I have a good sleep" at the beginning and "I have a bad sleep" at the end.

$\mathrm{FIQ}$ is an evaluation instrument for FMS. It measures components of health status that are affected by FMS. The total score ranges from 0 to 100 and high scores indicate more severe symptoms ${ }^{(17)}$.

BDI is a 21-item scale most widely used for measuring the symptoms and severity of depression. Each item is scored between 0 and 3 , with higher scores indicating more severe disease. Total score is obtained by the sum of the scores and interpreted as follows: $0-10$ : no depression, 11-17: mild depression, 18-23: moderate depression, 24 or above: severe depression ${ }^{(18,19)}$.

MMSE is a 30 -item test that is used for measuring cognitive impairment in clinical and researchs ${ }^{(20,21)}$.

\section{Statistical Analysis}

NCSS (Number Cruncher Statistical System) 2007 Statistical Software (Utah, USA) was used for the statistical analyses in this study. In evaluation of data, descriptive statistics (mean \pm standard deviation), together with independent samples $t$ test for normally distributing data, Mann Whitney $U$ test for non-normally distributing data and chi square test for the qualitative analyses, were used. The associations of variables with each other were determined according to Pearson correlation test. The $p$ value $<0.05$ was regarded as statistically significant. In the comparison of MPV levels between the patient $(n=15)$ and the control ( $n=15)$ groups, it was found that the effect power was 0.719 as a result of the plot study conducted with a total of 30 cases in both groups. As a result of the power analysis performed for $5 \%$ error and $80 \%$ power, it was determined that the number of cases to be included in the patient and control groups should be 32 , with a minimum of 64 in both groups totally.

\section{RESULTS}

Totally 54 patients and 33 control cases were included in the study. General characteristics and laboratory data of study participants are summarized in Table 1.

Social characteristics and symptoms of study participants are summarized in Table 2.

There was not any statistically significant difference regarding age, weight, height and $\mathrm{BMI}$, between control and FMS groups $(p>0.05)$. The mean number of children in the FMS group was statistically significantly higher than that of the control group ( $p=0.0001)$. There was not a statistically significant difference between both groups for leucocyte, and platelet counts, hemoglobin, MPV, CRP, urea, creatinine uric acid, ALT, AST, ALP, calcium, phosphorus, $25 \mathrm{OH}$ Vitamin D, PTH and TSH levels, $(p>0.05)$. The mean hematocrit levels were statistically significantly lower in the FMS group than control group ( $p=0.045)$. On the other hand, sedimentation levels $(p=0.03)$, mean VAS pain and VAS sleep values $(p=0.0001)$, FMS 1990ACR, disseminated pain index, symptom severity scale score, pain localization score, symptom effect score, fibromyalgia syndrome impact q score and Beck depression index were statistically significantly higher in the FMS group compared with the control group ( $p=0.0001)$. The mean of MMSE score was statistically significantly lower in the FMS group than control group $(p=0.0001)$.

There was not a statistically significant difference between 2 groups regarding educational level, marital status, job, and smoking status or habitual alcohol use $(p>0.05)$.

Symptoms including fatigue, morning stiffness, sleep disturbances, paresthesia, headache, irritable bowel syndrome, sicca symptoms, female urethral syndrome, sensation of tissue swelling and dysmenorrhea were statistically significantly higher in the FMS group compared with the control group. However, there was not a significant difference between groups regarding the presence of Raynaud's phenomena ( $p=0.069$ ). 
Table 1. General characteristics and laboratory data of study participants.

\begin{tabular}{|c|c|c|c|}
\hline Characteristics & $\begin{array}{c}\text { Control Group } \\
(n: 33)\end{array}$ & $\begin{array}{l}\text { FMS Group } \\
(n: 54)\end{array}$ & p \\
\hline Age (years) & $33.7 \pm 6.42$ & $35.31 \pm 9.12$ & 0.377 \\
\hline Height $(\mathrm{cm})$ & $162.55 \pm 6.05$ & $162.89 \pm 6.32$ & 0.805 \\
\hline Weight (kg) & $64.39 \pm 12.94$ & $69.17 \pm 14.11$ & 0.119 \\
\hline BMI $\left(\mathrm{kg} / \mathrm{m}^{2}\right)$ & $24.31 \pm 4.27$ & $26.1 \pm 5.2$ & 0.101 \\
\hline $\begin{array}{l}\text { Number of } \\
\text { children }\end{array}$ & $0.73 \pm 0.94$ & $2.28 \pm 1.7$ & 0.0001 \\
\hline Leucocyte count & $6.91 \pm 1.31$ & $7.11 \pm 1.86$ & 0.597 \\
\hline Hemoglobin & $12.69 \pm 1.34$ & $12.23 \pm 1.08$ & 0.086 \\
\hline Hematocrit & $38.04 \pm 3.35$ & $36.69 \pm 2.76$ & 0.045 \\
\hline Platelet & $253.91 \pm 50.34$ & $273.58 \pm 78.42$ & 0.202 \\
\hline MPV & $7.34 \pm 0.99$ & $21.95 \pm 106.36$ & 0.433 \\
\hline Sedimentation & $15.61 \pm 10.19$ & $21.94 \pm 14.38$ & 0.03 \\
\hline CRP & $0.45 \pm 0.45$ & $0.53 \pm 0.35$ & 0.359 \\
\hline Urea & $26.12 \pm 6.95$ & $24.83 \pm 5.75$ & 0.352 \\
\hline Creatinine & $0.6 \pm 0.1$ & $0.66 \pm 0.3$ & 0.278 \\
\hline Uric acid & $3.79 \pm 0.94$ & $3.93 \pm 0.85$ & 0.477 \\
\hline ALT & $17.94 \pm 9.39$ & $19.13 \pm 7.97$ & 0.529 \\
\hline AST & $21.67 \pm 9.5$ & $19.22 \pm 6.37$ & 0.154 \\
\hline ALP & $60.31 \pm 16.24$ & $65.77 \pm 17.77$ & 0.162 \\
\hline Calcium & $9.54 \pm 0.37$ & $9.38 \pm 1.3$ & 0.490 \\
\hline Phosphor & $3.25 \pm 0.51$ & $3.47 \pm 0.66$ & 0.105 \\
\hline $25 \mathrm{OH}$ vitamin $\mathrm{D}^{*}$ & $18.98 \pm 11.46$ & $17.64 \pm 12.46$ & 0.689 \\
\hline PTH* & $53.54 \pm 22.33$ & $41.75 \pm 48.45$ & 0.324 \\
\hline TSH & $1.49 \pm 0.73$ & $1.69 \pm 0.91$ & 0.296 \\
\hline VAS pain & $20.45 \pm 20.93$ & $82.69 \pm 18.98$ & 0.0001 \\
\hline VAS sleep & $33.94 \pm 31.27$ & $76.85 \pm 23.68$ & 0.0001 \\
\hline FMS 1990ACR & $3.06 \pm 3.05$ & $14.07 \pm 1.73$ & 0.0001 \\
\hline $\begin{array}{l}\text { Disseminated } \\
\text { pain index }\end{array}$ & $3.12 \pm 3.09$ & $12.59 \pm 3.6$ & 0.0001 \\
\hline $\begin{array}{l}\text { Symptom sever- } \\
\text { ity scale score }\end{array}$ & $2.61 \pm 1.68$ & $9 \pm 1.44$ & 0.0001 \\
\hline $\begin{array}{l}\text { Pain localization } \\
\text { score }\end{array}$ & $4.42 \pm 4.95$ & $17.39 \pm 5.02$ & 0.0001 \\
\hline $\begin{array}{l}\text { Symptom effect } \\
\text { score }\end{array}$ & $21.64 \pm 15.83$ & $61.13 \pm 15.38$ & 0.0001 \\
\hline $\begin{array}{c}\text { Fibromyalgia } \\
\text { syndrome effect } \\
\text { score }\end{array}$ & $25.91 \pm 16.37$ & $62.91 \pm 15.89$ & 0.0001 \\
\hline $\begin{array}{l}\text { Beck depression } \\
\text { index }\end{array}$ & $8.91 \pm 6.98$ & $17.98 \pm 9.92$ & 0.0001 \\
\hline $\begin{array}{l}\text { Mini-mental } \\
\text { score }\end{array}$ & $29.64 \pm 0.74$ & $24.72 \pm 3.88$ & 0.0001 \\
\hline
\end{tabular}

BMI: Body mass index MPV:Mean platelet volume $C R P: C$ reactive protein PTH: Parathormon TSH: Thyroid stimulating hormone

VAS: Visual analogue scale
Table 2. Social characteristics and symptoms of study participants

\begin{tabular}{|c|c|c|c|c|c|c|}
\hline \multirow{5}{*}{$\begin{array}{l} \\
\text { Educa- } \\
\text { tional } \\
\text { Level }\end{array}$} & & \multicolumn{2}{|c|}{$\begin{array}{c}\text { Control } \\
\text { Group (n:33) }\end{array}$} & \multicolumn{2}{|c|}{$\begin{array}{c}\text { FMS Group } \\
\text { (n:54) }\end{array}$} & \multirow{2}{*}{$\begin{array}{c}\mathbf{p} \\
0.336\end{array}$} \\
\hline & $\begin{array}{l}\text { Primary } \\
\text { school }\end{array}$ & 16 & $48.48 \%$ & 33 & $61.11 \%$ & \\
\hline & $\begin{array}{l}\text { Mid- } \\
\text { school }\end{array}$ & 4 & $12.12 \%$ & 6 & $11.11 \%$ & \\
\hline & $\begin{array}{l}\text { High } \\
\text { school }\end{array}$ & 11 & $33.33 \%$ & 10 & $18.52 \%$ & \\
\hline & University & 6 & $18.18 \%$ & 5 & $9.26 \%$ & \\
\hline \multirow{4}{*}{$\begin{array}{l}\text { Mari- } \\
\text { tal } \\
\text { status }\end{array}$} & Single & 8 & $24.24 \%$ & 7 & $12.96 \%$ & \multirow[t]{4}{*}{0.523} \\
\hline & Married & 22 & $66.67 \%$ & 43 & $79.63 \%$ & \\
\hline & Widow & 2 & $6.06 \%$ & 2 & $3.70 \%$ & \\
\hline & Divorced & 1 & $3.03 \%$ & 2 & $3.70 \%$ & \\
\hline \multirow[t]{5}{*}{ Job } & Housewife & 22 & $66.67 \%$ & 41 & $75.93 \%$ & \multirow[t]{5}{*}{0.801} \\
\hline & Employee & 4 & $12.12 \%$ & 5 & $9.26 \%$ & \\
\hline & $\begin{array}{c}\text { Govern- } \\
\text { ment } \\
\text { official }\end{array}$ & 5 & $15.15 \%$ & 4 & $7.41 \%$ & \\
\hline & $\begin{array}{l}\text { Profession } \\
\text { libérale }\end{array}$ & 1 & $3.03 \%$ & 2 & $3.70 \%$ & \\
\hline & Student & 1 & $3.03 \%$ & 2 & $3.70 \%$ & \\
\hline \multicolumn{2}{|c|}{ Smoking } & 6 & $18.18 \%$ & 11 & $20.75 \%$ & 0.771 \\
\hline \multicolumn{2}{|c|}{ Alcohol } & 2 & $6.06 \%$ & 1 & $1.89 \%$ & 0.305 \\
\hline \multicolumn{2}{|c|}{ Fatigue } & 23 & $69.70 \%$ & 54 & $100.00 \%$ & 0.0001 \\
\hline \multicolumn{2}{|c|}{ Morning stiffness } & 11 & $33.33 \%$ & 50 & $92.59 \%$ & 0.0001 \\
\hline \multicolumn{2}{|c|}{ Sleep disturbance } & 8 & $24.24 \%$ & 48 & $88.89 \%$ & 0.0001 \\
\hline \multicolumn{2}{|c|}{ Morning fatigue } & 17 & $51.52 \%$ & 51 & $94.44 \%$ & 0.0001 \\
\hline \multicolumn{2}{|c|}{ Paresthesia } & 2 & $6.06 \%$ & 42 & $77.78 \%$ & 0.0001 \\
\hline \multicolumn{2}{|c|}{ Headache } & 11 & $33.33 \%$ & 47 & $87.04 \%$ & 0.0001 \\
\hline \multicolumn{2}{|c|}{$\begin{array}{c}\text { Raynaud's phe- } \\
\text { nomena }\end{array}$} & 2 & $6.06 \%$ & 11 & $20.37 \%$ & 0.069 \\
\hline \multicolumn{2}{|c|}{$\begin{array}{l}\text { Irritable bowel } \\
\text { syndrome }\end{array}$} & 4 & $12.12 \%$ & 17 & $31.48 \%$ & 0.041 \\
\hline \multicolumn{2}{|c|}{ Sicca symptoms } & 1 & $3.03 \%$ & 14 & $25.93 \%$ & 0.006 \\
\hline \multicolumn{2}{|c|}{$\begin{array}{l}\text { Female urethral } \\
\text { syndrome }\end{array}$} & 0 & $0.00 \%$ & 14 & $25.93 \%$ & 0.001 \\
\hline \multicolumn{2}{|c|}{$\begin{array}{c}\text { Sensation of tissue } \\
\text { swelling }\end{array}$} & 7 & $21.21 \%$ & 30 & $55.56 \%$ & 0.002 \\
\hline \multicolumn{2}{|c|}{ Dysmenorrhea } & 3 & $9.09 \%$ & 26 & $48.15 \%$ & 0.0001 \\
\hline
\end{tabular}

In the control group, there was not a statistically significant correlation between uric acid or MPV levels and age, VAS pain, VAS sleep, FMS 1990 ACR, disseminated pain index, symptom severity scale score, pain localization score, symptom effect score, fibromyalgia syndrome effect score, Beck depression index and MMSE score ( $p>0.05)$. Although there was not a statistically significant correlation between BMI and MPV levels; there was a significant, and positive correlation 
between BMI and uric acid levels ( $r=0,664 p=0.0001)$.

In the FMS group, there was not a statistically significant correlation between uric acid or MPV levels and age, disease duration, VAS pain, VAS sleep, FMS 1990 $A C R$, disseminated pain index, symptom severity scale score, symptom effect score, fibromyalgia syndrome impact questionnaire score, Beck depression index and MMSE score $(p>0.05)$. On the other hand, there was a statistically significant, and positive correlation between uric acid and BMI ( $r=0.454 \mathrm{p}=0.001)$, but a statistically significant, and negative correlation between uric acid and pain localization score $(r=-0.349 \mathrm{p}=0.011)$.These findings are summarized in Table 3.

Table 3. Results of correlation analysis of some general characteristic features and laboratory data of study participants with MPV and uric acid levels

\begin{tabular}{|c|c|c|c|c|c|}
\hline & \multicolumn{3}{|c|}{ Control Group } & \multicolumn{2}{|c|}{ FMS Group } \\
\hline & & MPV & Uric acid & MPV & Uric acid \\
\hline \multirow[t]{2}{*}{ Age } & $r$ & -0.165 & 0.336 & 0.117 & 0.066 \\
\hline & p & 0.358 & 0.056 & 0.399 & 0.64 \\
\hline \multirow[t]{2}{*}{ BMI } & $\mathbf{r}$ & -0.091 & 0.664 & 0.019 & 0.454 \\
\hline & $\mathbf{p}$ & 0.615 & 0.0001 & 0.894 & 0.001 \\
\hline \multirow{2}{*}{$\begin{array}{l}\text { Disease } \\
\text { duration }\end{array}$} & $r$ & . & . & -0.029 & -0.123 \\
\hline & $\mathbf{p}$ & . & . & 0.857 & 0.443 \\
\hline \multirow[t]{2}{*}{ VAS Pain } & $r$ & -0.199 & 0.134 & 0.053 & 0.06 \\
\hline & $\mathbf{p}$ & 0.268 & 0.456 & 0.703 & 0.674 \\
\hline \multirow[t]{2}{*}{ VAS Sleep } & $r$ & -0.07 & 0.109 & 0.077 & -0.137 \\
\hline & p & 0.698 & 0.544 & 0.578 & 0.332 \\
\hline \multirow[t]{2}{*}{ FMS 1990ACR } & $r$ & -0.11 & 0.069 & -0.006 & -0.011 \\
\hline & $\mathbf{p}$ & 0.543 & 0.702 & 0.965 & 0.939 \\
\hline \multirow{2}{*}{$\begin{array}{l}\text { Disseminated } \\
\text { Pain Index }\end{array}$} & $\mathbf{r}$ & -0.114 & -0.188 & 0.091 & -0.217 \\
\hline & p & 0.529 & 0.295 & 0.512 & 0.122 \\
\hline \multirow{2}{*}{$\begin{array}{l}\text { Symptom } \\
\text { Severity } \\
\text { Scale Score }\end{array}$} & $r$ & -0.035 & 0.063 & 0.095 & -0.051 \\
\hline & p & 0.845 & 0.726 & 0.495 & 0.72 \\
\hline \multirow{2}{*}{$\begin{array}{l}\text { Pain Localization } \\
\text { Score }\end{array}$} & $r$ & -0.054 & -0.024 & 0.1 & -0.349 \\
\hline & p & 0.764 & 0.892 & 0.474 & 0.011 \\
\hline \multirow{2}{*}{$\begin{array}{l}\text { Symptom } \\
\text { Effect Score }\end{array}$} & $\mathbf{r}$ & -0.093 & -0.039 & 0.078 & -0.164 \\
\hline & p & 0.607 & 0.828 & 0.578 & 0.246 \\
\hline \multirow{2}{*}{$\begin{array}{l}\text { Fibromyalgia } \\
\text { Syndrome } \\
\text { Effect Score }\end{array}$} & $r$ & -0.065 & -0.189 & -0.15 & 0.115 \\
\hline & p & 0.718 & 0.292 & 0.279 & 0.416 \\
\hline \multirow{2}{*}{$\begin{array}{l}\text { Beck Depression } \\
\text { Index }\end{array}$} & $r$ & 0.022 & 0.024 & -0.129 & 0.052 \\
\hline & p & 0.903 & 0.895 & 0.357 & 0.719 \\
\hline \multirow[t]{2}{*}{ MMSE Score } & $\mathbf{r}$ & -0.142 & 0.029 & 0.196 & 0.055 \\
\hline & $\mathbf{p}$ & 0.429 & 0.871 & 0.172 & 0.709 \\
\hline
\end{tabular}

\section{DISCUSSION}

In this study we have evaluated the cognitive functions of patients with FMS and aimed to determine the effects of uric acid and MPV levels on cognitive functions in this group of patients. We have determined that, MMSE results of FMS patients were statistically significantly lower than those of age and gendermatched control cases, displaying a cognitive impairment in this group. We did not determine any correlation between cognitive functions and uric acid or MPV levels in FMS patients. To the best of our knowledge, this is the first study in the literature evaluating the effects of uric acid and MPV levels on cognitive functions of FMS patients.

In the literature, there are some investigations regarding the cognitive impairments in FMS patients but with small patient groups ${ }^{(22)}$. Although in 2010 ACR criteria, in symptom severity scale, the severity of cognitive functions directly support the diagnosis ${ }^{(23)}$; the results of studies about the cognitive functions in FMS have failed to arrive 0 at a general consensus. RodríguezAndreu J et al compared the MMSE results of FMS patients with controls per diagnosis of neuropathic (NeP) or mixed pain (MP) and reported a slight but statistically significantly lower score in the adjusted MMSE score in FMS group and high frequency of cognitive impairment compared with the population reference value ${ }^{(24)}$. Leavitt et al especially reported a significant level of cognitive deficit in FMS patients in the absence of rehearsal ${ }^{25}$. Luerding et al studied 20 FMS patients and reported significantly reduced working memory and impaired non-verbal long-term memory when compared with normative data derived from age- and education-matched control groups ${ }^{(26)}$. Tesio et al reported the presence of impairments of attention, long-term memory, working memory in FMS patients compared with healthy controls based on a self-reported questionnaire ${ }^{(27)}$. On the other hand, Mohs et al assessed the cognitive functions by Symbol Digit Substitution Test, Trail-Making Test and Verbal Learning and Recall Tests in FMS patients who were under fluoxetine treatment and did not determine any cognitive impairment ${ }^{(28)}$. In another recent study, FMS patients showed normal performance in executive functioning and decision-making and pain was associated with neuropsychological functioning but anxiety, depression and medications were not ${ }^{(29)}$. de Melo LF and Da-Silva 
SL evaluated the MMSE results of FMS patients with rheumatoid arthritis and systemic lupus erythematosis patients; and did not determine any statistically significant difference regarding the test results among 3 groups. However, the mean MMSE result was 23.07 in FMS group, where the cut-off point was 24 , defining a mild impairment ${ }^{(30)}$. In our study, we have also determined a statistically significant decrease in MMSE scores and a cognitive impairment in FMS patients.

Serum uric acid is an endogenous antioxidant. The association of serum uric acid levels with cognitive impairment has been studied in some diseases. However recent results in literature are conflicting. Cicero et al assessed the cognitive functions of 288 healthy young participants by MMSE and determined a positive association between serum uric acid levels and cognitive dysfunction in young elderly subject. Similarly, Chen et al reported a positive correlation between the degree of cognitive symptoms and serum uric acid levels in patients with essential tremor and Parkinson's disease ${ }^{(31)}$. On the other hand, high plasma urate levels were associated with slower rate of cognitive decline in mild cognitive impairment in 3 years follow-up of 747 patients ${ }^{(8)}$. Vannorsdall et al followed 423 cognitively healthy community-dwelling older women for 9 years and reported that higher baseline serum uric acid levels were associated with poorer working memory, but there was no correlation between baseline serum uric acid levels and global cognitive functioning ${ }^{(32)}$. We also could not determine an association between serum uric acid levels and cognitive functions in FMS patients.

The studies about the association of MPV levels and cognitive functions are also limited in number. Liang et al reported significantly reduced MPV levels as cognitive levels declined and showed that MPV levels were significantly associated with MMSE ${ }^{(33)}$. Koç et al reported elevated MPV levels in patients with Alzheimer's disease but in that study when the patients were divided into 2 subgroups as having mild or moderate cognitive impairments according to MMSE scores, there was not any statistically significant difference between moderate and the mild groups regarding MPV values ${ }^{(15)}$. We also could not determine an association between serum MPV levels and cognitive functions. Mild cognitive impairment of FMS patients may be due to low Beck depression scores of these patients relative to control groups.
Nevertheless, small sample size and cross-sectional design are the main limitations of this study. Thus, a direct cause and effect relationship cannot be established.

\section{Conclusion}

FMS is a common disease and complaints of FMS patients regarding cognitive impairments are increasing day by day. We have determined declined cognitive functions in FMS patients compared with the control cases. In that aspect, factors affecting the cognitive functions gain importance. Although we could not determine an association of serum uric acid and MPV levels with cognitive functions, larger prospective studies with longer follow- up periods are warranted to elucidate the role of these biomarkers in FMS patients.

Ethics Committee Approval: Bakırkoy Dr. Sadi Konuk Training and Research Hospital Ethics Committee approval was received (4/1/2016; 2019.01.05).

Conflict of Interest: No conflict of interest was declared by the authors.

Funding: No funding was used for this study.

Informed Consent: Written consent was obtained from all patients participating in the study.

\section{REFERENCES}

1. Vincent A, Lahr BD, Wolfe F, et al. Prevalence of fibromyalgia: a population-based study in Olmsted County, Minnesota, utilizing the Rochester Epidemiology Project. Arthritis Care Res (Hoboken). 2013;65(5):786-92. https://doi.org/10.1002/acr.21896

2. Wolfe F, Smythe HA, Yunus MB, Bennett RM, Bombardier C, Goldenberg DL, et al. The American College of Rheumatology Criteria for the classification of fibromyalgia. Report of the Multicenter Criteria Committee. Arthritis Rheum. 1990;33(2):16072. https://doi.org/10.1002/art.1780330203

3. Grisart J, Van der Linden M, Masquelier E. Controlled processes and automaticity in memory functioning in fibromyalgia patients: relation with emotional distress and hypervigilance. J Clin Exp Neuropsychol. 2002;24(8):994-1009. https://doi.org/10.1076/jcen.24.8.994.8380

4. Amris K, Waehrens EE, Jespersen A, Bliddal H, DanneskioldSamsoe B. Observation-based assessment of functional ability in patients with chronic widespread pain: a cross-sectional study. Pain. 2011;152(11):2470-6. https://doi.org/10.1016/j.pain.2011.05.027

5. Sommer C, Hauser W, Alten R, Petzke F, Spath P, Tölle T, et al. Drug therapy of fibromyalgia syndrome. Systematic review, meta-analysis and guideline. Schmerz. 2012;26(3):297-310. https://doi.org/10.1007/s00482-012-1172-2

6. Cahill-Smith S, Li JM. Oxidative stress, redox signalling and endothelial dysfunction in ageing-related neurodegenerative diseases: a role of NADPH oxidase 2. Br J Clin Pharmacol. 2014;78(3):441- 
53. doi: 10.1111/bcp.12357. https://doi.org/10.1111/bcp.12357

7. Kuzkaya N, Weissmann N, Harrison DG, Dikalov S. Interactions of peroxynitrite with uric acid in the presence of ascorbate and thiols: implications for uncoupling endothelial nitric oxide synthase. Biochem Pharmacol. 2005;70(3):343-54. https://doi.org/10.1016/j.bcp.2005.05.009

8. Irizarry MC, Raman R, Schwarzschild MA, Becerra LM, Thomas RG, Peterson RC, et al. Plasma urate and progression of mild cognitive impairment. Neurodegener Dis. 2009;6(1-2):23-8. https://doi.org/10.1159/000170883

9. De Giorgi A, Fabbian F, Pala M, et al. Uric acid: friend or foe? Uric acid and cognitive function "Gout kills more wise men than simple". Eur Rev Med Pharmacol Sci. 2015;19(4):640-6. PMID: 25753882.

10. Cicero AF, Desideri G, Grossi G, et al. Serum uric acid and impaired cognitive function in a cohort of healthy young elderly: data from the Brisighella Study. Intern Emerg Med. 2015;10(1):2531. https://doi.org/10.1007/s11739-014-1098-z

11. Baune BT. Inflammation and neurodegenerative disorders: is there still hope for therapeutic intervention? Curr Opin Psychiatry. 2015;28(2):148-54. https://doi.org/10.1097/YCO.0000000000000140

12. Gasparyan AY, Ayvazyan L, Mikhailidis DP, Kitas GD. Mean platelet volume: a link between thrombosis and inflammation? Curr Pharm Des. 2011;17(1):47-58. https://doi.org/10.2174/138161211795049804

13. Gunluoglu G, Yazar EE, Veske NS, Seyhan EC, Altin S. Mean platelet volume as an inflammation marker in active pulmonary tuberculosis. Multidiscip Respir Med. 2014 28;9(1):11. https://doi.org/10.1186/2049-6958-9-11

14. Özer S, Yılmaz R, Sönmezgöz E, et al. Simple markers for subclinical inflammation in patients with Familial Mediterranean Fever. Med Sci Monit. 2015;21:298-303. https://doi.org/10.12659/MSM.892289

15. Koç ER, Uzar E, Çirak Y, Parlak Demir Y, Ilhan A. The increase of mean platelet volume in patients with Alzheimer disease. Turk J Med Sci. 2014;44(6):1060-6. https://doi.org/10.3906/sag-1212-5

16. Folstein MF, Folstein SE, Mc Hugh PR. "Mini-mental state". A practical method for grading the cognitive state of patients for the clinician. J Psychiatr Res. 1975;12(3):189-98. https://doi.org/10.1016/0022-3956(75)90026-6

17. Burckhardt CS, Clark SR, Bennett RM. The fibromyalgia impact questionnaire: development and validation. I Rheumatol 1991;18(5):728 -33. PMID: 1865419.

18. Nordahl HM, Stiles TC. Personality styles in patients with fibromyalgia, major depression and healthy controls. Ann Gen Psychiatry. 2007;6:9. https://doi.org/10.1186/1744-859X-6-9

19. Beck AT, Ward CH, Mendelson M, Mock J, Erbaugh J. An inventory for measuring depression. Arch Gen Psychiatry. 1961;4:56171. https://doi.org/10.1001/archpsyc.1961.01710120031004

20. Arevalo-Rodriguez I, Smailagic N, Roqué I Figuls $M$, et al. MiniMental State Examination (MMSE) for the detection of Alzheimer's disease and other dementias in people with mild cognitive impairment $(\mathrm{MCl})$. Cochrane Database Syst Rev. 2015;2015(3):CD010783.

https://doi.org/10.1002/14651858.CD010783.pub2
21. Koziarska D, Wunsch E, Milkiewicz M, Wójcicki M, Nowacki $\mathrm{P}$, Milkiewicz P. Mini-Mental State Examination in patients with hepatic encephalopathy and liver cirrhosis: a prospective, quantified electroencephalography study. BMC Gastroenterol. 2013;13:107. https://doi.org/10.1186/1471-230X-13-107

22. Gelonch O, Garolera M, Rosselló L, Pifarré J. Cognitive dysfunction in fibromyalgia. Rev Neurol. 2013;56(11):573-88. https://doi.org/10.33588/rn.5611.2013016

23. Wolfe F, Clauw DJ, Fitzcharles MA, et al. The American College of Rheumatology preliminary diagnostic criteria for fibromyalgia and measurement of symptom severity. Arthritis Care Res (Hoboken). 2010;62(5):600-10. https://doi.org/10.1002/acr.20140

24. Rodríguez-Andreu J, Ibáñez-Bosch R, Portero-Vázquez A, Masramon X, Rejas J, Gálvez R. Cognitive impairment in patients with fibromyalgia syndrome as assessed by the mini-mental state examination. BMC Musculoskelet Disord. 2009;10:162. https://doi.org/10.1186/1471-2474-10-162

25. Leavitt F, Katz RS. Normalizing memory recall in fibromyalgia with rehearsal: a distraction counteracting effect. Arthritis Rheum. 2009;61(6):740-4. https://doi.org/10.1002/art.24559

26. Luerding R, Weigand T, Bogdahn U, Schmidt-Wilcke T. Working memory performance is correlated with local brain morphology in the medial frontal and anterior cingulate cortex in fibromyalgia patients: structural correlates of pain-cognition interaction. Brain. 2008;131(Pt 12):3222-31. https://doi.org/10.1093/brain/awn229

27. Tesio V, Torta DM, Colonna F, et al. Are fibromyalgia patients cognitively impaired? Objective and subjective neuropsychological evidence. Arthritis Care Res (Hoboken). 2015;67(1):14350. https://doi.org/10.1002/acr.22403

28. Mohs R, Mease P, Arnold LM, et al. The effect of duloxetine treatment on cognition in patients with fibromyalgia. Psychosom Med. 2012;74(6):628-34. https://doi.org/10.1097/PSY.0b013e31825b9855

29. Cuevas-Toro AM, López-Torrecillas F, Díaz-Batanero MC, PérezMarfil MN. Neuropsychological function, anxiety, depression and pain impact in fibromyalgia patients. Span J Psychol. 2014;17:E78. https://doi.org/10.1017/sjp.2014.78

30. de Melo LF, Da-Silva SL. Neuropsychological assessment of cognitive disorders in patients with fibromyalgia, rheumatoid arthritis, and systemic lupus erythematosus. Rev Bras Reumatol. 2012;52(2):181-8. PMID: 22460408. https://doi.org/10.1590/S0482-50042012000200003

31. Chen J, Yao J, Wu Y, Chen Y, Mao C, Liu C. Cognitive dysfuctions associated with essential tremor and Parkinson's disease. Zhonghua Yi Xue Za Zhi. 2014;94(31):2412-6. https://doi.org/10.3760/cma.j.issn.0376-2491.2014.31.005.

32. Vannorsdall TD, Kueider AM, Carlson MC, Schretlen DJ. Higher baseline serum uric acid is associated with poorer cognition but not rates of cognitive decline in women. Exp Gerontol. 2014;60:136-9. https://doi.org/10.1016/j.exger.2014.10.013

33. Liang QC, Jin D, Li Y, Wang RT. Mean platelet volume and platelet distribution width in vascular dementia and Alzheimer's disease. Platelets. 2014;25(6):433-8. h ttps://doi.org/10.3109/09537104.2013.831064 